\title{
Effect of Different Substrates on Soil Microbial Community Structure and the Mechanisms of Reductive Soil Disinfestation
}

\author{
Xingyan Tan 1,2, Hongkai Liao 1,3, Liangzuo Shu ${ }^{2 *}$ and Huaiying Yao ${ }^{1,3,4 *}$ \\ ${ }^{1}$ Ningbo Key Lab of Urban Environment Process and Pollution Control, Ningbo Urban Environment Observation \\ and Research Station, Institute of Urban Environment, Chinese Academy of Sciences, Ningbo, China, ${ }^{2}$ School of Life \\ Sciences, Huaibei Normal University, Key Laboratory of Plant Resources and Biology of Anhui Province, Huaibei, China, \\ ${ }^{3}$ Key Lab of Urban Environment and Health, Institute of Urban Environment, Chinese Academy of Sciences, Xiamen, China, \\ ${ }^{4}$ Research Center for Environmental Ecology and Engineering, Wuhan Institute of Technology, Wuhan, China
}

OPEN ACCESS

Edited by:

Christopher Rensing,

Fujian Agriculture and Forestry

University, China

Reviewed by:

Xinqi Huang,

Nanjing Normal University, China

Binbin Liu,

Institute of Genetics and

Developmental Biology (CAS), China

*Correspondence:

Liangzuo Shu

Shulz69@163.com

Huaiying Yao

hyyao@iue.ac.cn

Specialty section:

This article was submitted to Microbiotechnology, Ecotoxicology

and Bioremediation,

a section of the journal

Frontiers in Microbiology

Received: 08 September 2019

Accepted: 25 November 2019

Published: 11 December 2019

Citation:

Tan X, Liao H, Shu L and Yao H

(2019) Effect of Different Substrates

on Soil Microbial Community

Structure and the Mechanisms

of Reductive Soil Disinfestation.

Front. Microbiol. 10:2851.

doi: 10.3389/fmicb.2019.02851
Reductive soil disinfestation (RSD) has recently attracted much attention owing to its effectiveness for controlling pathogens. In this study, we aimed to evaluate the effects of different $\mathrm{C} / \mathrm{N}$ substrates on RSD and to explore the changes in microbial community structure during RSD treatment. The experimental set up included 10 groups, as follows: CK, without substrates; RSD treatments with alfalfa (Medicago sativa L.)[AL], maize (Zea mays Linn. Sp.) straw [MS], and rice (Oryza sativa L.) straw [RS], with three levels of addition (0.5\% [L], 2\% [M], and 5\% [H]), yielding ALL, ALM, ALH, MSL, MSM, MSH, RSL, RSM, and RSH groups. Compared with CK, RSD treatments significantly increased the content of $\mathrm{NH}_{4}^{+}-\mathrm{N}$, and effectively eliminated the accumulated $\mathrm{NO}_{3}^{-}-\mathrm{N}$ in the soil. The relative abundances of organic acid producers, including Clostridium, Coprococcus, and Oxobacter, in all RSD groups were significantly higher than those in the CK by day 21. Moreover, on day 21, Aspergillus and Fusarium in all RSD groups were significantly lower than those in the CK. In summary, RSD treatments clearly increased the relative abundances of organic acid generators and effectively inhibited pathogens; however, when the $\mathrm{C} / \mathrm{N}$ was too low and the amount of addition too high, ammonia poisoning and rapid growth of some microorganisms (e.g., Pseudallescheria and Arthrographis) may occur.

Keywords: reductive soil disinfestation, tomato, organic matter, $\mathrm{C} / \mathrm{N}$ ratio, soil microbial community

\section{INTRODUCTION}

Tomatoes are a global economic crop and China is the leading producer of tomatoes worldwide. However, as the cultivation period increases, accumulation of soil-borne plant pathogens in the soil also increases (Fu et al., 2017). These pathogens can survive in the soil for long periods, thereby impairing plant growth. Traditional chemical fungicides have been phased out because of increasing concerns regarding sustainable development of agriculture and human health (Butler et al., 2012; Huang et al., 2016). 
Therefore, non-chemical soil sterilization methods, including reductive soil disinfestation (RSD) have been rapidly developed.

Reductive soil disinfestation refers to the addition of easily decomposable organic matter to the soil, saturation of the soil with water, and then covering of the soil with a plastic film and incubation at a high temperature for 3-4 weeks; this kills pathogens by creating anaerobic reducing conditions (Momma et al., 2013; Butler et al., 2014). This method was developed in the Netherlands in the year 2000 and has now been applied to many crop production systems (Blok et al., 2000), including tomatoes (Di Gioia et al., 2017; Guo et al., 2018), potatoes (Messiha et al., 2007), strawberries (Shennan et al., 2014), and watermelons (Liu et al., 2018), which are prone to the problems associated with continuous cropping. RSD has significant effects on inhibition of soil-borne diseases. For example, in an anaerobic environment, some aerobic pathogens will not survive (SerranoPérez et al., 2017). Additionally, the organic acids produced during the decomposition of organic matter can effectively kill some soil-borne plant pathogens, including Fusarium oxysporum (Butler et al., 2012; Huang et al., 2014; Meng et al., 2017). Significant changes in the microbial community structure have also been noted after RSD treatment (Huang et al., 2016; Guo et al., 2018; Mazzola et al., 2018), and rapid growth of anaerobic bacteria can lead to decreases in aerobic pathogens.

The choice of organic matter is important for disease control under anaerobic conditions. RSD uses easily decomposable organic matter, such as plant residues, diluted ethanol, molasses, or manure (Di Gioia et al., 2017; Zhao et al., 2018). The application of different organic materials in RSD treatment may result in different effects. Wen et al. (2015) found that application of maize straw in RSD treatment can effectively inhibit Artemisia selengensis root rot pathogens and the inhibition efficiency can reach $90 \%$ when the application rate is $2 \%$. The combined application of molasses and composted poultry litter has been shown to have strong effects on inhibiting fungi and nematodes (Rosskopf et al., 2014). Additionally, the separate use of molasses can also suppress F. oxysporum (Butler et al., 2012). Wheat bran used as the carbon source in RSD can control Fusarium wilt by reducing the viability of $F$. oxysporum f. sp. lycopersici chlamydospores (Momma et al., 2006; Mowlick et al., 2012). Treatment with crop straw has also been explored in China (Gadde et al., 2009; Li et al., 2018).

Examining the effects of substrate input amount on pathogens may facilitate optimization of the application rate of organic matter (Wen et al., 2015). Although previous studies have shown that greater input of organic material increases pathogen inhibition (Blok et al., 2000), the amount of organic material added needs to be controlled based on the growth of crops in the soil. Additionally, the amount of soil-borne pathogens can be significantly reduced, and the community structure of microorganisms can be clearly changed, by using RSD to treat continuous cropping soil. However, few studies have evaluated the specific trends in microbial community structure during soil treatment. Therefore, in this study, we aimed to investigate the effects of different $\mathrm{C} / \mathrm{N}$ substrates on RSD and explore specific changes in the community structure of bacteria and fungi by RSD during soil treatment and after tomato planting.

\section{MATERIALS AND METHODS}

\section{Soil Sampling and Experimental Design}

The soils used in this test were from a greenhouse located in Changzhou, Jiangsu Province $\left(31^{\circ} 55^{\prime}, 119^{\circ} 51^{\prime}\right)$, East China. The soils were rotated for tomato cultivation for the past 4 years, and soil samples were collected after the tomatoes were harvested. Physical and chemical properties of soils were as follows: $\mathrm{pH} 6.60$; total $\mathrm{N} 1.47 \mathrm{~g} \mathrm{~kg}^{-1}$; total $\mathrm{P} 0.66 \mathrm{~g} \mathrm{~kg}^{-1}$; total $\mathrm{K} 9.06 \mathrm{~g} \mathrm{~kg}^{-1}$; $\mathrm{NH}_{4}^{+}-\mathrm{N} 25.47 \mathrm{mg} \mathrm{kg}{ }^{-1} ; \mathrm{NO}_{3}^{-}-\mathrm{N} 473.41 \mathrm{mg} \mathrm{kg}^{-1}$; and organic matter $21.94 \mathrm{~g} \mathrm{~kg}^{-1}$.

Pots $(15 \mathrm{~cm} \times 15 \mathrm{~cm})$ were filled with $2 \mathrm{~kg}$ soil, and treatments were set up as follows: (1) CK, without substrate; (2) ALL, RSD with $0.5 \%$ alfalfa [AL] (Medicago sativa L.) (substrate/soil ratio [w/w], the same below); (3) ALM, RSD with 2\% AL; (4) ALH, RSD with 5\% AL; (5) MSL, RSD with $0.5 \%$ maize straw [MS] (Zea mays Linn. Sp.); (6) MSM, RSD with 2\% MS; (7) MSH, RSD with 5\%MS; (8) RSL, RSD with $0.5 \%$ rice straw [RS] (Oryza sativa L.); (9) RSM, RSD with $2 \%$ RS; (10) RSH, RSD with $5 \%$ $\mathrm{RS}$. The $\mathrm{C} / \mathrm{N}$ ratios of the three substrates used in the test are shown in Table 1. Each treatment included three replicates. All treatments were cultured at $35^{\circ} \mathrm{C}$ for 21 days under flooding and covered with transparent plastic film (Thickness $=0.12 \mathrm{~mm}$ ). Sampling was performed on days 7, 14, and 21. After 21 days, the plastic films were removed, and the soils in all treatments were drained for 1 week and dried. Next, 21-day-old tomato seedlings, each with the same growth, were selected and transplanted into the pots. The tomato plants were incubated in a walk-in incubator, with average day and night temperatures of 30 and $20^{\circ} \mathrm{C}$, respectively, during the tomato growth period. Moreover, the soils were equally amended with urea $\left(100 \mathrm{mg} \mathrm{N} \mathrm{kg}^{-1}\right)$ and $\mathrm{KH}_{2} \mathrm{PO}_{4}\left(100 \mathrm{mg} \mathrm{K} \mathrm{kg}^{-1}\right)$ for all treatments. The tomato plants were harvested after 60 days, and rhizosphere soil samples were collected after planting.

\section{Soil Characteristics and Plant Nutrient Analysis}

Soil $\mathrm{pH}$ was measured in a 1:2.5 (v/v) soil/water ratio using an Accumet XL600 pH meter (Fisher Scientific, Inc., United States). Soil dissolved organic carbon (DOC) was extracted with $0.5 \mathrm{M}$ $\mathrm{K}_{2} \mathrm{SO}_{4}$ at a soil/solution ratio of 1:5 and detected using a TOC$\mathrm{VCPH} / \mathrm{CPN}$ analyzer (Shimadzu Inc., Japan). Soil $\mathrm{NO}_{3}^{-}-\mathrm{N}$ and $\mathrm{NH}_{4}^{+}-\mathrm{N}$ was extracted with $1 \mathrm{M} \mathrm{KCl}$ at a soil/solution ratio of $1: 10$ on a shaker for $60 \mathrm{~min}$ at $250 \mathrm{rpm}$ at $25^{\circ} \mathrm{C}$. The extract was filtered, and the concentrations of $\mathrm{NO}_{3}^{-}-\mathrm{N}$ and $\mathrm{NH}_{4}^{+}-\mathrm{N}$ were determined with a continuous-flow analyzer (SAN ++ ; Skalar, Breda, Holland).

TABLE 1 | Nutrient contents of maize, rice straw, and alfalfa.

\begin{tabular}{lccc}
\hline & Total $\mathbf{~}\left(\mathbf{g ~ k g}^{\mathbf{- 1}} \mathbf{)}\right.$ & Total $\mathbf{C}\left(\mathbf{g ~ k g}^{\mathbf{- 1}} \mathbf{)}\right.$ & C:N ratio \\
\hline Alfalfa (AL) & 31.51 & 455.80 & 14.47 \\
Maize straw (MS) & 13.48 & 456.33 & 33.80 \\
Rice straw (RS) & 5.87 & 404.78 & 68.61
\end{tabular}




\section{DNA Extraction and Real-Time Quantitative Polymerase Chain Reaction (qPCR)}

A FastDNA Spin Kit for Soil (MP Biomedicals, Cleveland, $\mathrm{OH}$, United States) was used for extraction of DNA from $0.5 \mathrm{~g}$ soil samples according to the manufacturer's recommendations. Next, the quality and concentration of DNA were detected using a NanoDrop 2000 spectrophotometer (Thermo, Waltham, MA, United States). The DNA samples were stored in a $-20^{\circ} \mathrm{C}$ refrigerator for subsequent analysis.

qPCR amplification was performed on a Light-Cycler Roche 480 instrument (Roche Molecular Systems, Switzerland). The reaction system had a total volume of $20 \mu \mathrm{L}$, including $10 \mu \mathrm{L}$ Go Taq qPCR master mix (Promega, Madison, WI, United States), $0.4 \mu \mathrm{L}$ forward and reverse primers (10 $\mu \mathrm{M})$, and $1 \mu \mathrm{L}$ template DNA. The abundances of bacteria and fungi were determined using the 16S rRNA geneV4-V5 and ITS1 region respectively, and using the primer pair 515F (GTGCCAGCMGCCGCGG)/907R (CCGTCAATTCMTTTRAGTTT) and ITS1F (CTTGGTCATT TAGAGGAAGTAA)/ITS2R (GCTGCGTTCTTCATCGATGC), respectively. The conditions for bacterial $16 \mathrm{~S}$ rRNA gene qPCR amplification were based on the protocol described by Long et al. (2018). The thermal cycling conditions for the fungal internal transcribed spacer (ITS) gene were as follows: an initial denaturation step at $95^{\circ} \mathrm{C}$ for $5 \mathrm{~min}$; followed by 45 cycles of $95^{\circ} \mathrm{C}$ for $15 \mathrm{~s}, 55^{\circ} \mathrm{C}$ for $40 \mathrm{~s}, 72^{\circ} \mathrm{C}$ for $45 \mathrm{~s}$, and $84^{\circ} \mathrm{C}$ for $15 \mathrm{~s}$ (fluorescence intensity detection); a final extension at $72^{\circ} \mathrm{C}$ for $60 \mathrm{~s}$; and finally, melting curve analysis. All standard curves were prepared by a 10 -fold gradient dilution method for environmental sample plasmid DNA, and the $\mathrm{R}^{2}$ values of the standard curves of bacteria and fungi were greater than 0.9992 and 0.9965 , respectively. The amplification efficiencies of qPCR for bacteria and fungi were greater than $95 \%$ and $90 \%$, respectively.

\section{Illumina HiSeq2500 Sequencing and Data Processing}

In total, 120 DNA samples $(10$ treatments $\times$ three replicates $\times$ four time points) were selected for HiSeq. DNA samples were subjected to sequencing at Biotechnologies, Inc. (Beijing, China) on an Illumina HiSeq instrument (United States). The bacterial 16S rRNA gene V4-V5 region was amplified using $515 \mathrm{~F}$ and the individual barcode reverse primer 907R (Xu et al., 2012; Long et al., 2016), and ITS1F and the individual barcode reverse primer ITS2R (Huang et al., 2016) were used to amplify the fungal ITS1 region. The results of high-throughput sequencing have been uploaded to NCBI (SRA accession: PRJNA523309).

The default settings of the Quantitative Insights into Microbial Ecology (QIIME 1.9.1) platform were used for analysis of bacterial 16S rRNA genes and fungal ITS genes (Caporaso et al., 2010). Only the targeting sequence was retained in subsequent analyses. Operational taxonomic units (OTUs) were identified with a cutoff of $97 \%$ similarity using RDP classifier (Claesson et al., 2009). The annotation databases for $16 \mathrm{~S}$ rRNA gene sequencing data and fungal ITS region sequencing data are the Greengenes database (13.8) and the UNITE database (12.11), respectively. For bacteria, the sampling depth for rarefaction curve analysis was optimized to 21590 sequences for soil DNA samples during RSD treatments and 26911 sequences for soil DNA samples after tomato planting. For fungi, the sampling depth for rarefaction curve analysis was optimized to 15118 sequences for soil DNA samples during RSD treatments and 3402 sequences for soil DNA samples after tomato planting.

\section{Community Data and Statistical Analysis}

The rarefied OTU table for each treatment was used to calculate the microbial community alpha-diversity. Principal coordinate analysis (PCoA) was performed based on both weighted_unifrac and Bray_Curtis distance matrices in bacteria and fungi, respectively, to visualize the pairwise community dissimilarities between samples. Duncan tests $(P<0.05)$ in IBM SPSS 20.0 (SPSS, Inc., Chicago, IL, United States)were used to test significant differences among treatments by one-way analysis of variance, and the significant differences in soil microbial community structures have been analyzed using PERMANOVA.

\section{RESULTS}

\section{Changes in Soil Properties During RSD Treatment}

Compared with the CK group, on days 14 and 21, the $\mathrm{pH}$ of all RSD treatments was clearly increased. At the end of incubation, the $\mathrm{pH}$ values were highest in the ALH and ALM groups (Figure 1A). Input of organic matter increased the content of soluble DOC in the soil. For the same substrate treatment, the content of DOC increased as the amount added increased. Moreover, over time, the DOC content in each group gradually decreased (Figure 1B). On days 7, 14, and 21, sampling results indicated that the $\mathrm{NH}_{4}^{+}-\mathrm{N}$ content in all RSD treatments was higher than that in the $\mathrm{CK}$ group. Following treatment with MS and AL, the $\mathrm{NH}_{4}^{+}-\mathrm{N}$ content increased as the amount of substrate added increased over time. At the end of the $\mathrm{RSD}$, the $\mathrm{NH}_{4}^{+}-\mathrm{N}$ content in the $\mathrm{ALH}$ group reached up to $978.8 \mathrm{mg} \mathrm{kg}^{-1}$ (Figure 1C). However, throughout the entire soil treatment period, the $\mathrm{NH}_{4}^{+}-\mathrm{N}$ content in the rice straw treatment group was maintained at a lower concentration at all three treatment levels. In contrast, the RSD treatment clearly eliminated the $\mathrm{NO}_{3}^{-}-\mathrm{N}$ in soil. Additionally, RSD treatments reduced the $\mathrm{NO}_{3}^{-}-\mathrm{N}$ content in the soil to a lower level within 7 days. However, the results of the $\mathrm{CK}$ treatment showed that flooding alone could not eliminate the $\mathrm{NO}_{3}^{-}-\mathrm{N}$ accumulated in the soil (Figure 1D).

\section{Effects of Tomato Planting on Soil Properties and Plant Biomass}

After the tomato planting, the $\mathrm{pH}$ was lower and the $\mathrm{NH}_{4}^{+}-\mathrm{N}$ and DOC contents were significantly higher in the ALH group than in the other groups. Additionally, in the ALH group, the $\mathrm{NO}_{3}^{-}-\mathrm{N}$ content reached up to $279.5 \mathrm{mg} \mathrm{kg}^{-1}$, second only 


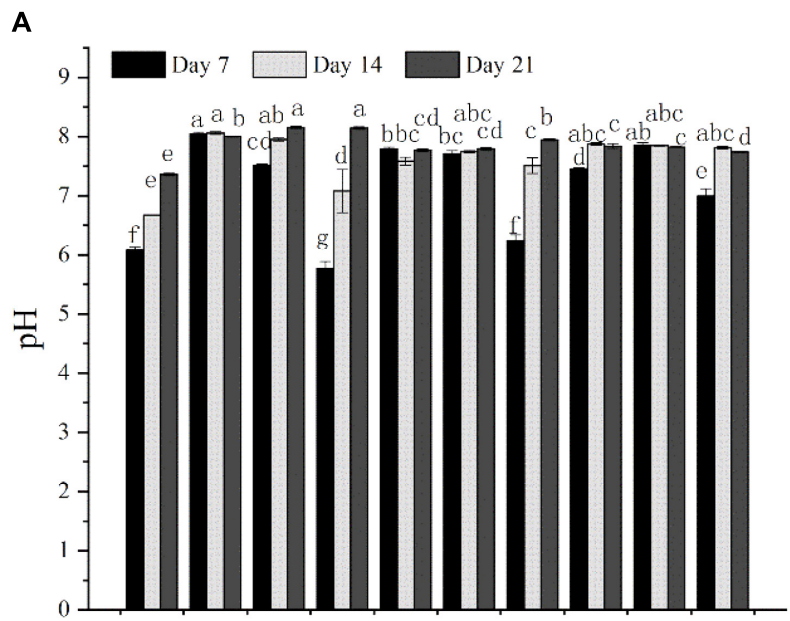

CK ALL ALM ALH MSL MSM MSH RSL RSM RSH

C

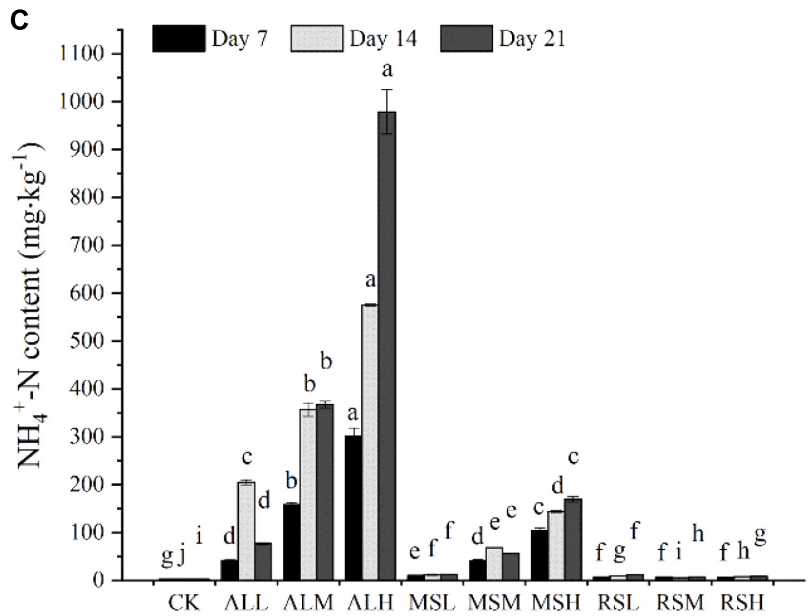

B

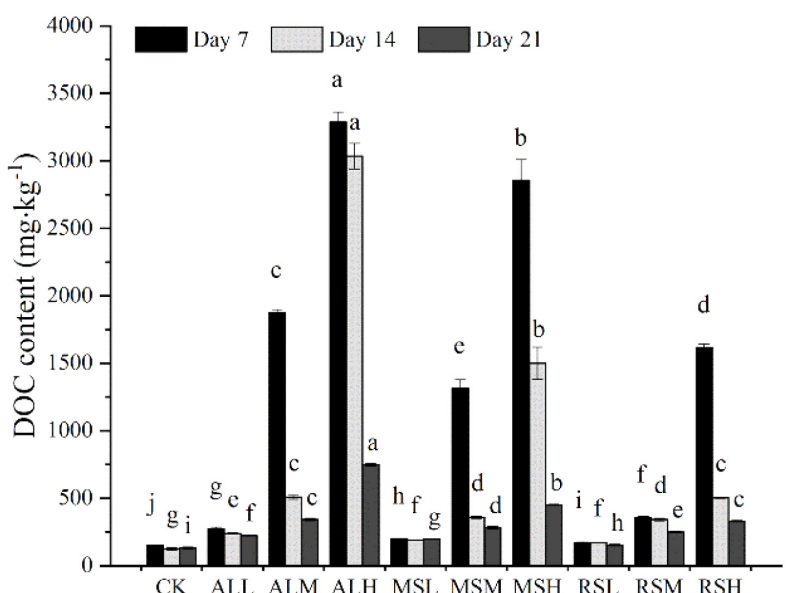

CK ALL ALM ALH MSL MSM MSH RSL RSM RSH

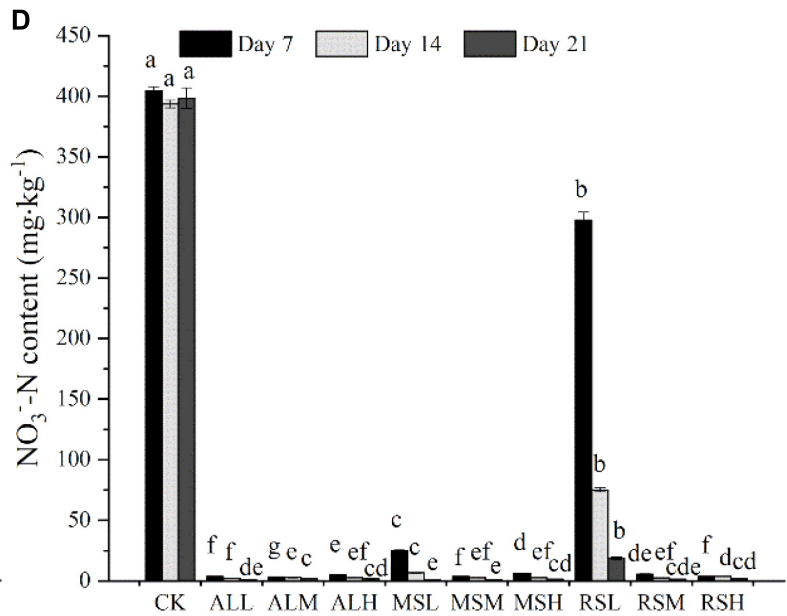

FIGURE 1 | The soil pH (A), DOC content (B), ammonia nitrogen content (C), and nitrate nitrogen content (D) during RSD. Bars with different letters represent significant differences among the 10 treatments at the same time, as determined using Duncan's tests $(P<0.05)$. Error bars indicate standard errors.

to the CK group (Supplementary Figures S1a-d). The results of $\mathrm{NH}_{4}^{+}-\mathrm{N}$ analysis showed that MS, RS, and AL treatments showed similar trends; $5 \%$ addition of the substrate yielded significantly higher $\mathrm{NH}_{4}^{+}-\mathrm{N}$ levels than $0.5 \%$ and $2 \%$ substrate (Supplementary Figure S1b). Analysis of DOC contents yielded similar results (Supplementary Figure S1c). In soil samples with MS and RS treatments, the $\mathrm{NO}_{3}^{-}-\mathrm{N}$ contents tended to decrease as the amount of added substrate increased; the opposite trend was observed in soils treated with AL (Supplementary Figure S1d).

Leaf dry weight decreased in the following order, with significant $(P<0.05)$ differences represented by " $>$ ": $\mathrm{MSL}>\mathrm{MSM}>\mathrm{MSH}, \mathrm{RSL}>\mathrm{RSM}>\mathrm{RSH}, \mathrm{ALL}>\mathrm{ALM}>\mathrm{ALH}$, and MSL $>$ ALL $>$ RSL. Stem and root dry weight showed the same results in MS and AL treatments. However, in RS treatments, the results of stem and root dry weight were not significantly different at the three input levels. After cultivation for 60 days, the plant height and stem diameter in the MSL group were notably higher than in the other treatments. Additionally, plant height and stem diameter were $36.9 \%$ and $23.1 \%$ greater, respectively, than in the CK group (Supplementary Table S1).

\section{Changes in Bacterial Microbial Community Structure During RSD Treatment}

\section{Fluctuation of Bacterial Population}

From days 7 to 14 , bacterial 16S rRNA gene copies in the CK, MSM, MSH, RSL, RSH, and ALM groups varied significantly $(P<0.05$, Supplementary Figure S2). However, from day 21 to after tomato planting, only the bacterial $16 \mathrm{~S}$ rRNA gene copies in the CK and MSL groups were significantly altered $(P<0.05)$. Additionally, after tomato planting, the bacterial $16 \mathrm{~S}$ rRNA gene copies in all RSD treatments were higher than those in the CK group. For all three substrate treatments, the population of bacteria in the treatment with $5 \%$ added substrate was clearly higher than those in treatments with $0.5 \%$ and $2 \%$ added substrate (Figure 2).

\section{Soil Bacterial Composition}

During soil treatment, the dominant phyla across all samples were Acidobacteria, Actinobacteria, Bacteroidetes, Fibrobacteres, 


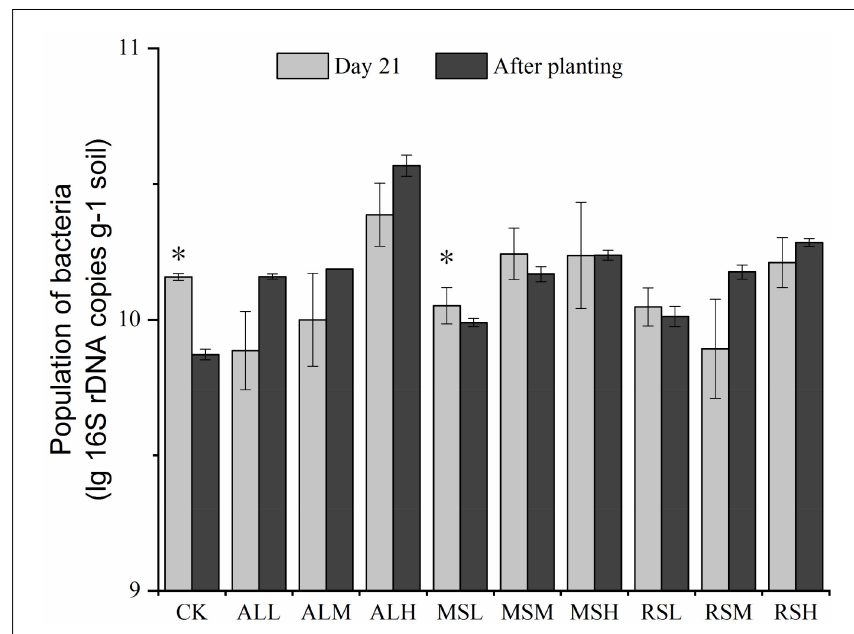

FIGURE 2 | Determination of bacterial populations in samples from the 10 treatments at different time points. Error bars represent standard errors of the means of three replicates. ${ }^{*} P<0.05$.

Firmicutes, Nitrospirae, and Proteobacteria (Figure $\mathbf{3 A}$ and Supplementary Figures S3a,b). Compared with the CK group, the relative abundance of Firmicutes phyla increased in all RSD treatments, and the higher substrate addition improved the relative abundance of Firmicutes. On days 7 and 14, there were negative relationships between the relative abundance of Firmicutes and the $\mathrm{C} / \mathrm{N}$ ratio of the substrate. Additionally, on day 21, the relative abundance of Firmicutes in all RSD treatments tended to be the same, except for that in the ALH group. The bacterial community composition in all treatments tended to become more and more similar after planting of the tomatoes (Figure 3B). The relative abundance of Proteobacteria in all treatments was higher than $35 \%$, making this the dominant phylum after tomato planting (Figure 3B).

The bacterial community structure changed in the soil over time, the initially dominant genera of bacteria gradually disappeared, and the relative abundances of the various genera became balanced (Supplementary Figures S4a-c). At the end of soil incubation (day 21), the ALH treatment significantly increased the relative abundances of Caloramator, Oxobacter, and Sedimentibacter compared with that in other treatments. Moreover, the relative abundances of Clostridium and Coprococcus were notably higher for all RSD treatments than those in the CK treatment, which were lower than $1 \%$ within 21 days (Table 2). During soil incubation, compared with 5\% substrate addition, $0.5 \%$ substrate addition distinctly increased the relative abundances of Flavisolibacter and Symbiobacterium in the MS and AL treatments (Supplementary Figures S4a-c). On day 21, the highest relative abundances of Bacillus and Desulfosporosinus were found in the AL treatments, and lower substrate amounts were associated with higher relative abundances of Bacillus and Desulfosporosinus. For Kaistobacter spp., the relative abundance was significantly higher in the CK group than in all RSD treatments. After tomato planting, the relative abundances of Stenotrophomonas, Pseudomonas, and Brevundimonas were obviously higher in the ALH group than in the other groups. The relative abundance of Bacillus decreased in the following order, where " $>$ " represents a significant difference $(P<0.05)$ and " $=$ " represents no significant difference $(P>0.05)$ : MSL $>$ MSH, RSL $>$ RSH, ALL $>$ ALH, ALL $>$ MSL $=$ RSL $>$ CK. The relative abundance of Clostridium in CK, MSL, RSL, and RSM groups was clearly lower than that in other treatments, with that in the ALM group showing the highest abundance. The relative abundances of Flavisolibacter in the MSL and RSM groups reached as high as $5.0 \%$ and $4.3 \%$, respectively, showing significantly higher levels than in other treatments. In the Acidobacteria phylum, compared with $5 \%$ and $2 \%$ substrate addition, $0.5 \%$ substrate addition distinctly increased the relative abundances of Streptomyces in the MS, RS, and AL treatments (Table 3 and Supplementary Figure S4d).

\section{PCoA of Bacterial Communities}

During the 3-week study period, PCoA showed that RSD treatments significantly $(P=0.001)$ influenced soil bacterial community structures compared with the $\mathrm{CK}$ treatment. During soil treatment, the bacterial community structures tended to diverge first and then converge (Figure $\mathbf{4 A}$ and Supplementary Figures S5a,b). Compared with the bacterial community structure after RSD treatments, the microbial community structure in the soil was changed after tomato planting (Figures 4A,B).

\section{Changes in Fungal Microbial Community Structure During RSD Treatment}

\section{Fluctuation of Fungal Population}

On day 7 , the copies of fungal ITS genes decreased in the following order: $0.5 \%>2 \%>5 \%(P<0.05)$. On day 14 , the numbers of fungal ITS genes did not differ significantly in all groups except for the CK, MSM, MSH, and RSL groups as compared with day 7 (Supplementary Figure S6). However, compared with that before tomato planting, tomato planting notably increased the copies of fungal ITS genes in the soil $(P<0.05$; Figure 5).

\section{Soil Fungal Composition}

During soil treatment, Ascomycota was the dominant phylum in all soils, with a relative abundance higher than 90\% (Figure 6A and Supplementary Figures S7a,b). However, after planting tomatoes, although the relative abundance of Ascomycota was the highest, the relative abundance of Basidiomycota was increased in all soils (Figure 6B).

Specifically, at the fungal genus level, significant variations were observed in relative abundances of dominant genera (Table 2 and Supplementary Figures S8a-c). During soil treatments, the relative abundances of Aspergillus and Fusarium in the RSD treatments tended to decrease over time. However, by day 21, the relative abundance of Aspergillus in CK still remained high (47.6\%), and the relative abundances of Aspergillus and Fusarium were significantly higher than those in all RSD treatments. Notably, at the end of soil treatment, compared with $\mathrm{CK}$ treatment, the ALH and 


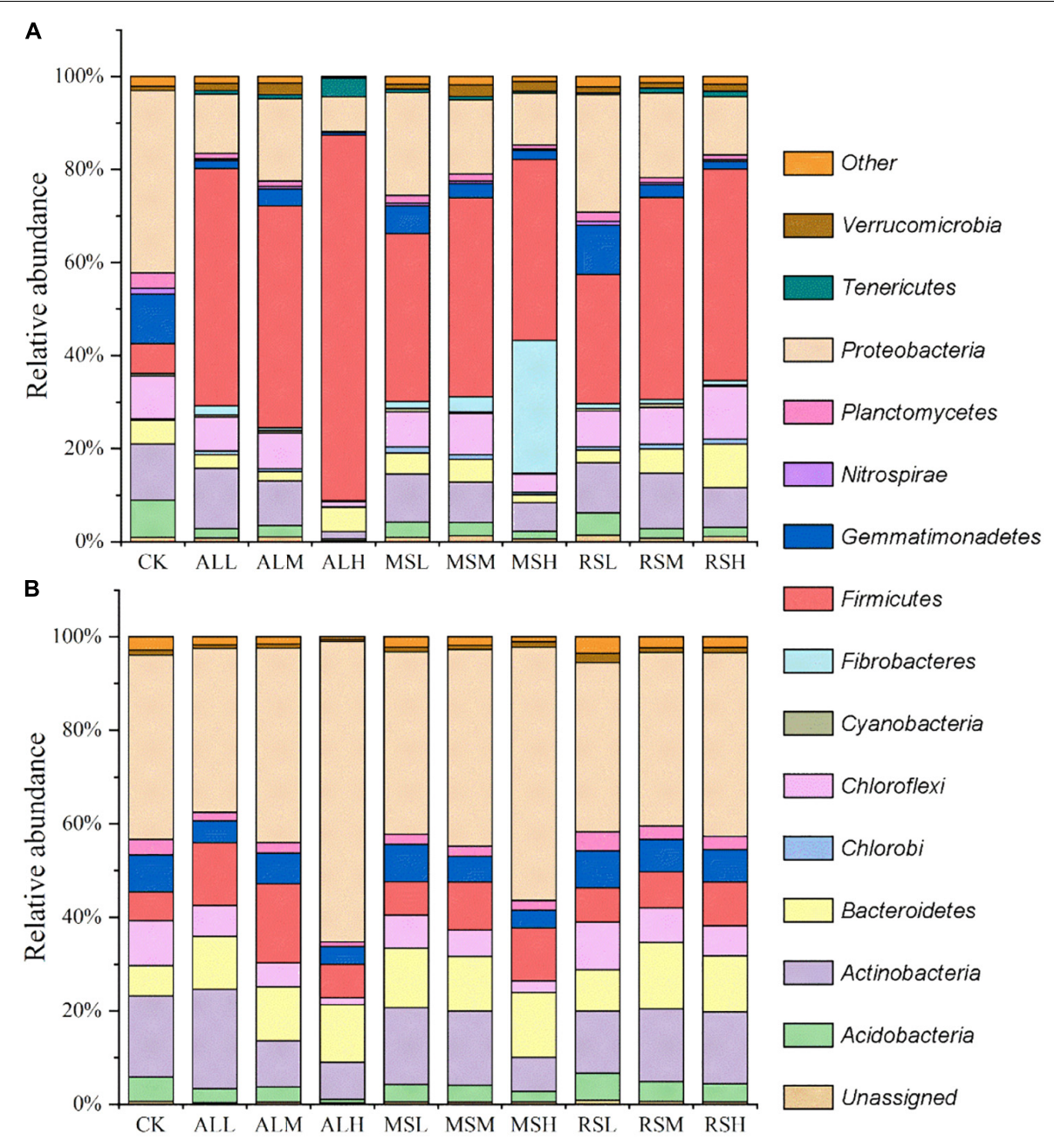

FIGURE 3 | Relative abundances (\%) of individual taxonomic groups of the bacterial phyla present in samples from the 10 treatments. (A,B) Day 21 and after tomato planting, respectively. Bacterial phyla with relative abundances lower than $1 \%$ in all the treatments were clustered as "other."

$\mathrm{MSH}$ treatments clearly reduced the relative abundances of Acremonium, also leading to a dramatic increase in the relative abundance of Pseudallescheia. After tomato planting, the relative abundance of Aspergillus was significantly higher in the CK group than in all RSD treatments, and its relative abundance in the CK group exceeded $50 \%$ of all fungi. Similar to Aspergillus, the relative abundance of Fusarium was the highest in the CK group, and there were no clear differences between all RSD treatments (Table 3). For the Arthrographis genera, the relative abundances in the ALM and ALH groups were obviously higher than in the other groups, reaching up to $25.5 \%$ and $62.7 \%$, respectively (Table 3 and Supplementary Figure S8d).

\section{PCoA of Fungal Communities}

During soil treatments, compared with the CK treatment, the fungal community structures of RSD treatments gradually changed over time. When the $\mathrm{C} / \mathrm{N}$ ratio and the added amount of the substrate differed, the response of the fungal community also differed (Figure 7A and Supplementary Figures S9a,b). After tomato planting, PCoA showed that the CK and ALH treatments were clearly $(P=0.001)$ separated from the other groups. However, the other eight groups clustered together $(P=0.1)$; that is, the fungal community structures in the MSL, MSM, MSH, RSL, RSM, RSH, ALL, and ALM groups tended to be similar after tomato planting (Figure 7B).

\section{DISCUSSION}

The $\mathrm{C} / \mathrm{N}$ ratio is a key factor in RSD treatment (Liu et al., 2016; Shrestha et al., 2018). The results of $\mathrm{NH}_{4}^{+}-\mathrm{N}$ content analysis showed that higher $\mathrm{C} / \mathrm{N}$ ratios were associated with lower $\mathrm{NH}_{4}^{+}-\mathrm{N}$ contents when the substrate input amount and treatment time were the same. Thus, the high $\mathrm{C} / \mathrm{N}$ ratio may limit $\mathrm{NH}_{4}^{+}-\mathrm{N}$ accumulation (Khalil et al., 2005). Because the amount of nitrogen consumed for carbon assimilation is constant, there will be less $\mathrm{N}$ remaining after carbon assimilation in the presence 
TABLE 2 | Relative abundances of dominant functional genera and pathogenic genera of bacteria and fungi during RSD treatment.

\begin{tabular}{|c|c|c|c|c|c|c|c|}
\hline & \multicolumn{4}{|c|}{ Bacteria } & \multicolumn{3}{|c|}{ Fungi } \\
\hline & \multicolumn{4}{|c|}{ Firmicutes (\%) } & \multicolumn{3}{|c|}{ Ascomycota (\%) } \\
\hline & Bacillus & Clostridium & Coprococcus & Desulfosporosinus & Aspergillus & Fusarium & Pseudallescheria \\
\hline \multicolumn{8}{|l|}{ Day 7} \\
\hline CK & $3.14 \pm 0.09 \mathrm{~g}^{\mathrm{a}}$ & $0.90 \pm 0.09 \mathrm{~g}$ & $0.54 \pm 0.05 \mathrm{de}$ & $0.09 \pm 0.01 e$ & $49.90 \pm 3.07 a$ & $2.85 \pm 0.17 b c$ & $0.89 \pm 0.04 a$ \\
\hline ALL & $10.05 \pm 0.75 \mathrm{~cd}$ & $3.76 \pm 0.50 \mathrm{ef}$ & $1.78 \pm 0.19 d$ & $1.13 \pm 0.10 \mathrm{~cd}$ & $50.80 \pm 7.24 a$ & $0.94 \pm 0.20 c$ & $3.37 \pm 1.84 a$ \\
\hline ALM & $18.60 \pm 1.24 a$ & $8.30 \pm 0.99 c$ & $6.17 \pm 0.37 b$ & $2.05 \pm 0.35 a b$ & $9.10 \pm 1.76 d$ & $2.34 \pm 0.39 c$ & $2.99 \pm 0.15 a$ \\
\hline ALH & $7.71 \pm 0.44$ def & $21.62 \pm 1.90 a$ & $3.59 \pm 0.55 c$ & $1.05 \pm 0.21 \mathrm{~cd}$ & $2.47 \pm 0.25 d$ & $3.11 \pm 2.46 b c$ & $2.95 \pm 0.78 a$ \\
\hline MSL & $6.22 \pm 0.86 \mathrm{efg}$ & $1.42 \pm 0.89 f g$ & $0.92 \pm 0.17 \mathrm{de}$ & $0.18 \pm 0.02 \mathrm{e}$ & $32.24 \pm 1.98 \mathrm{bc}$ & $2.17 \pm 0.27 c$ & $1.07 \pm 0.07 a$ \\
\hline MSM & $14.35 \pm 2.28 b$ & $7.27 \pm 1.49 \mathrm{~cd}$ & $5.23 \pm 0.76 b$ & $1.62 \pm 0.22 b c$ & $31.31 \pm 5.20 b c$ & $7.26 \pm 1.75 b$ & $1.06 \pm 0.19 a$ \\
\hline $\mathrm{MSH}$ & $10.07 \pm 1.25 \mathrm{~cd}$ & $15.24 \pm 0.38 b$ & $7.56 \pm 0.55 a$ & $2.78 \pm 0.66 a$ & $4.87 \pm 0.80 d$ & $15.95 \pm 3.29 a$ & $2.95 \pm 1.59 a$ \\
\hline RSL & $4.58 \pm 0.25 f g$ & $0.63 \pm 0.08 \mathrm{~g}$ & $0.48 \pm 0.02 \mathrm{e}$ & $0.10 \pm 0.01 \mathrm{e}$ & $42.78 \pm 5.23 \mathrm{ab}$ & $1.85 \pm 0.08 c$ & $1.31 \pm 0.11 a$ \\
\hline RSM & $7.89 \pm 0.20$ cde & $1.36 \pm 0.09 f g$ & $1.62 \pm 0.22 \mathrm{de}$ & $0.33 \pm 0.04 \mathrm{de}$ & $49.10 \pm 10.60 a$ & $1.25 \pm 0.30 c$ & $2.43 \pm 0.90 a$ \\
\hline $\mathrm{RSH}$ & $11.11 \pm 0.79 c$ & $5.22 \pm 0.41 \mathrm{de}$ & $5.89 \pm 0.34 b$ & $1.37 \pm 0.12 \mathrm{bc}$ & $26.82 \pm 1.36 c$ & $2.73 \pm 0.18 b c$ & $1.90 \pm 0.10 a$ \\
\hline \multicolumn{8}{|c|}{ Day 14} \\
\hline CK & $3.69 \pm 0.06 b c$ & $0.87 \pm 0.03 d$ & $0.55 \pm 0.04 c$ & $0.11 \pm 0.01 e$ & $52.01 \pm 3.12 a$ & $2.35 \pm 0.49 a$ & $1.11 \pm 0.21 a$ \\
\hline ALL & $13.98 \pm 1.66 \mathrm{a}$ & $3.81 \pm 0.25 d$ & $0.89 \pm 0.08 c$ & $0.77 \pm 0.02 c$ & $31.71 \pm 3.51 b$ & $0.08 \pm 0.040 \mathrm{e}$ & $7.03 \pm 2.13 a$ \\
\hline ALM & $2.86 \pm 0.39 c$ & $23.15 \pm 0.28 a$ & $3.45 \pm 0.33 b$ & $1.56 \pm 0.16 a b$ & $0.10 \pm 0.03 d$ & $0.50 \pm 0.27 \mathrm{de}$ & $0.05 \pm 0.02 a$ \\
\hline ALH & $4.18 \pm 1.70 \mathrm{bc}$ & $14.02 \pm 6.06 \mathrm{bc}$ & $7.28 \pm 1.70 \mathrm{a}$ & $0.61 \pm 0.08 \mathrm{~cd}$ & $0.54 \pm 0.22 d$ & $0.06 \pm 0.03 e$ & $18.94 \pm 15.77 a$ \\
\hline MSL & $5.65 \pm 0.19 b c$ & $1.45 \pm 0.16 d$ & $0.80 \pm 0.07 c$ & $0.34 \pm 0.10 \mathrm{cde}$ & $42.53 \pm 1.13 a b$ & $1.35 \pm 0.08 b c$ & $2.53 \pm 0.59 a$ \\
\hline MSM & $4.50 \pm 0.65 b c$ & $9.81 \pm 0.52 \mathrm{bcd}$ & $2.40 \pm 0.08 \mathrm{bc}$ & $1.30 \pm 0.11 b$ & $33.11 \pm 5.59 b$ & $1.67 \pm 0.12 b$ & $5.11 \pm 2.19 a$ \\
\hline $\mathrm{MSH}$ & $4.07 \pm 0.92 \mathrm{bc}$ & $16.59 \pm 6.02 \mathrm{ab}$ & $3.37 \pm 0.86 b$ & $1.75 \pm 0.30 a$ & $2.37 \pm 0.22 d$ & $0.95 \pm 0.15 c d$ & $3.07 \pm 1.24 a$ \\
\hline RSL & $4.22 \pm 0.25 b c$ & $0.81 \pm 0.06 d$ & $0.48 \pm 0.08 c$ & $0.09 \pm 0.01 e$ & $36.50 \pm 5.10 b$ & $1.80 \pm 0.30 a b$ & $3.25 \pm 0.74 a$ \\
\hline RSM & $6.66 \pm 1.04 b$ & $1.79 \pm 0.11 d$ & $1.34 \pm 0.10 c$ & $0.30 \pm 0.03 \mathrm{de}$ & $15.46 \pm 6.07 c$ & $0.48 \pm 0.10 \mathrm{de}$ & $26.48 \pm 23.88 a$ \\
\hline $\mathrm{RSH}$ & $5.22 \pm 1.07 \mathrm{bc}$ & $7.55 \pm 0.63 \mathrm{~cd}$ & $2.12 \pm 0.20 \mathrm{bc}$ & $1.21 \pm 0.26 b$ & $4.73 \pm 0.57 d$ & $0.18 \pm 0.03 e$ & $7.15 \pm 3.49 a$ \\
\hline \multicolumn{8}{|c|}{ Day 21} \\
\hline CK & $1.49 \pm 0.03 \mathrm{ef}$ & $0.74 \pm 0.07 f$ & $0.15 \pm 0.02 d$ & $0.05 \pm 0.01 e$ & $47.63 \pm 10.43 a$ & $2.75 \pm 0.44 a$ & $0.75 \pm 0.17 e$ \\
\hline ALL & $7.52 \pm 0.58 a$ & $6.37 \pm 0.06 b$ & $1.88 \pm 0.07 b$ & $0.70 \pm 0.04 a$ & $9.50 \pm 1.79 \mathrm{cde}$ & $0.06 \pm 0.02 d$ & $6.70 \pm 0.27 \mathrm{de}$ \\
\hline ALM & $2.15 \pm 0.09 \mathrm{cde}$ & $7.81 \pm 0.75 a$ & $1.51 \pm 0.14 b c$ & $0.67 \pm 0.08 a$ & $10.00 \pm 6.06 \mathrm{bcde}$ & $0.07 \pm 0.01 d$ & $19.88 \pm 6.44 c$ \\
\hline ALH & $1.19 \pm 0.18 f$ & $4.50 \pm 0.88 c$ & $5.09 \pm 0.51 a$ & $0.12 \pm 0.03 e$ & $0.42 \pm 0.19 \mathrm{e}$ & $0.02 \pm 0.01 d$ & $87.03 \pm 4.92 a$ \\
\hline MSL & $2.89 \pm 0.32 \mathrm{bc}$ & $2.99 \pm 0.15 e$ & $1.65 \pm 0.10 \mathrm{bc}$ & $0.24 \pm 0.02 d$ & $24.24 \pm 2.34 b$ & $0.81 \pm 0.11 b c$ & $9.43 \pm 1.50$ cde \\
\hline MSM & $1.45 \pm 0.18 \mathrm{ef}$ & $5.06 \pm 0.12 c$ & $1.39 \pm 0.20 b c$ & $0.54 \pm 0.04 b$ & $15.61 \pm 3.74 \mathrm{bcd}$ & $1.36 \pm 0.34 b$ & $9.14 \pm 4.37 \mathrm{cde}$ \\
\hline $\mathrm{MSH}$ & $2.37 \pm 0.19 \mathrm{~cd}$ & $7.03 \pm 0.15 a b$ & $4.64 \pm 0.56 a$ & $0.43 \pm 0.01 c$ & $1.57 \pm 0.41 \mathrm{de}$ & $0.51 \pm 0.21 \mathrm{~cd}$ & $63.76 \pm 4.82 b$ \\
\hline RSL & $1.98 \pm 0.15 \mathrm{def}$ & $4.22 \pm 0.36 \mathrm{~cd}$ & $1.05 \pm 0.06 \mathrm{bc}$ & $0.39 \pm 0.04 c$ & $22.91 \pm 1.98 \mathrm{bc}$ & $1.12 \pm 0.14 b$ & $5.59 \pm 0.55 \mathrm{de}$ \\
\hline RSM & $3.39 \pm 0.30 b$ & $3.22 \pm 0.02 \mathrm{de}$ & $1.46 \pm 0.07 \mathrm{bc}$ & $0.35 \pm 0.01 c$ & $12.75 \pm 4.09 \mathrm{bcde}$ & $0.12 \pm 0.01 d$ & $15.87 \pm 3.07 \mathrm{~cd}$ \\
\hline $\mathrm{RSH}$ & $1.68 \pm 0.09 \mathrm{def}$ & $4.47 \pm 0.05 c$ & $1.00 \pm 0.08 c$ & $0.55 \pm 0.01 b$ & $6.78 \pm 2.41 \mathrm{de}$ & $0.13 \pm 0.03 d$ & $6.04 \pm 1.55 \mathrm{de}$ \\
\hline
\end{tabular}

${ }^{a}$ Data are mean \pm standard error, and different lowercase letters indicate significant differences between treatments $(P<0.05)$.

of a high $\mathrm{C} / \mathrm{N}$ ratio (Rosskopf et al., 2015). In contrast, Butler (2014) observed that the high $\mathrm{C} / \mathrm{N}$ ratio of organic matter may cause loss of nitrogen. Moreover, previous studies (Mary et al., 1996) have also shown that organic amendment with a high $\mathrm{C} / \mathrm{N}$ ratio is more conducive to immobilization of nitrogen and that mineralization of low $\mathrm{C} / \mathrm{N}$ ratio organic residues is higher than that of high $\mathrm{C} / \mathrm{N}$ ratios during decomposition. In addition to mineralization, anaerobic conditions and high soil temperatures may also affect the activities of nitrifying soil bacteria (Butler et al., 2014; Rosskopf et al., 2015), leading to accumulation of $\mathrm{NH}_{4}^{+}-\mathrm{N}$. At the end of the RSD treatment, the $\mathrm{NH}_{4}^{+}-\mathrm{N}$ content in the ALH group (with the lowest $\mathrm{C} / \mathrm{N}$ ratio) was as high as $979 \mathrm{mg} \mathrm{kg}^{-1}$, which may result in ammonium toxicity. The results of $\mathrm{NO}_{3}^{-}-\mathrm{N}$ analysis showed that
RSD treatments could effectively eliminate $\mathrm{NO}_{3}^{-}-\mathrm{N}$ accumulated in the soil; lower $\mathrm{C} / \mathrm{N}$ ratios were associated with better effects. Increased DOC contents in the soil are conducive to the growth of soil microorganisms (Martínez-García et al., 2018), including bacteria related to denitrification. In our study, we found that when the substrate input amount and the treatment time were the same, the DOC content in the soil decreased as the $\mathrm{C} / \mathrm{N}$ ratio increased. Therefore, low $\mathrm{C} / \mathrm{N}$ ratios could provide more DOC for denitrifying bacteria and enhance denitrification, resulting in decreased $\mathrm{NO}_{3}^{-}-\mathrm{N}$ contents in the soil. An anaerobic environment also promotes this process. The products of denitrification are mainly $\mathrm{N}_{2} \mathrm{O}$ and $\mathrm{N}_{2}$, and release of $\mathrm{N}_{2} \mathrm{O}$ causes a greenhouse effect (Ciarlo et al., 2006). Thus, in order to reduce nitrogen losses, the release of greenhouse 
TABLE 3 | Relative abundances of dominant functional genera and pathogenic genera of bacteria and fungi in tomato rhizosphere soils.

\begin{tabular}{|c|c|c|c|c|c|c|c|}
\hline & \multicolumn{4}{|c|}{ Bacteria } & \multicolumn{3}{|c|}{ Fungi } \\
\hline & \multicolumn{2}{|c|}{ Firmicutes (\%) } & \multirow{2}{*}{$\begin{array}{c}\text { Acidobacteria (\%) } \\
\text { Streptomyces }\end{array}$} & \multirow{2}{*}{$\begin{array}{c}\text { Bacteroidetes (\%) } \\
\text { Flavisolibacter }\end{array}$} & \multicolumn{3}{|c|}{ Ascomycota (\%) } \\
\hline & Bacillus & Clostridium & & & Aspergillus & Fusarium & Arthrographis \\
\hline CK & $1.82 \pm 0.21 c^{a}$ & $0.47 \pm 0.03 e$ & $1.64 \pm 0.02 c$ & $0.30 \pm 0.03 e$ & $52.91 \pm 3.84 a$ & $2.35 \pm 0.74 a$ & $0.70 \pm 0.08 c$ \\
\hline ALL & $5.06 \pm 0.12 a$ & $0.99 \pm 0.02 d$ & $3.55 \pm 0.41 a$ & $3.05 \pm 0.44 b$ & $0.30 \pm 0.02 d$ & $0.08 \pm 0.01 b$ & $0.43 \pm 0.11 c$ \\
\hline ALM & $2.17 \pm 0.13 c$ & $4.40 \pm 0.30 a$ & $0.82 \pm 0.02 \mathrm{e}$ & $0.71 \pm 0.13 \mathrm{de}$ & $2.64 \pm 0.68 \mathrm{bcd}$ & $0.50 \pm 0.02 b$ & $25.53 \pm 2.09 b$ \\
\hline ALH & $1.94 \pm 0.24 c$ & $1.03 \pm 0.10 d$ & $0.48 \pm 0.10 \mathrm{e}$ & $0.26 \pm 0.04 \mathrm{e}$ & $0.80 \pm 0.11 \mathrm{~cd}$ & $0.36 \pm 0.16 b$ & $62.74 \pm 3.77 a$ \\
\hline MSL & $3.05 \pm 0.22 b$ & $0.30 \pm 0.03 e$ & $2.59 \pm 0.11 b$ & $5.00 \pm 0.36 a$ & $5.51 \pm 0.96 b$ & $0.78 \pm 0.18 b$ & $1.73 \pm 0.17 c$ \\
\hline MSM & $1.62 \pm 0.01 c$ & $2.40 \pm 0.13 c$ & $0.97 \pm 0.04 \mathrm{de}$ & $1.91 \pm 0.01 c$ & $5.13 \pm 0.64 \mathrm{bc}$ & $1.21 \pm 0.11 b$ & $0.32 \pm 0.05 c$ \\
\hline MSH & $2.19 \pm 0.30 c$ & $3.62 \pm 0.19 b$ & $0.53 \pm 0.05 e$ & $1.32 \pm 0.09 \mathrm{~cd}$ & $1.87 \pm 0.12 \mathrm{bcd}$ & $0.82 \pm 0.10 b$ & $0.15 \pm 0.04 c$ \\
\hline RSL & $2.89 \pm 0.22 b$ & $0.32 \pm 0.01 e$ & $1.48 \pm 0.34 \mathrm{~cd}$ & $1.37 \pm 0.03 \mathrm{~cd}$ & $1.77 \pm 0.26 \mathrm{bcd}$ & $0.98 \pm 0.71 b$ & $0.55 \pm 0.16 c$ \\
\hline RSM & $2.75 \pm 0.09 b$ & $0.27 \pm 0.02 e$ & $0.58 \pm 0.10 \mathrm{e}$ & $4.27 \pm 0.66 a$ & $0.93 \pm 0.08 \mathrm{~cd}$ & $0.25 \pm 0.08 b$ & $2.52 \pm 0.27 c$ \\
\hline $\mathrm{RSH}$ & $2.00 \pm 0.08 c$ & $1.22 \pm 0.11 d$ & $0.56 \pm 0.02 e$ & $1.65 \pm 0.14 c$ & $3.43 \pm 0.60 \mathrm{bcd}$ & $1.05 \pm 0.05 b$ & $0.47 \pm 0.07 c$ \\
\hline
\end{tabular}

${ }^{a}$ Data are mean \pm standard error, and different lowercase letters indicate significant differences between treatments $(P<0.05)$.

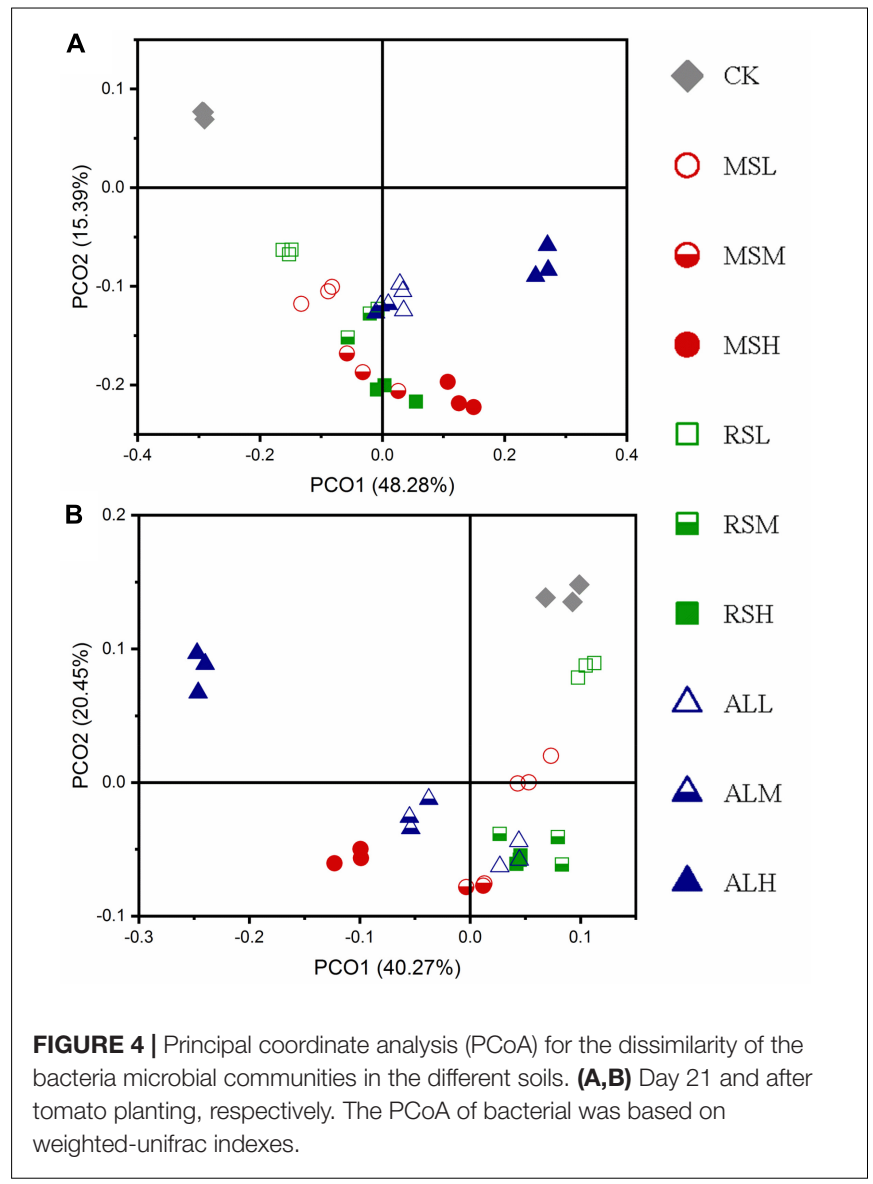

gases $\left(\mathrm{N}_{2} \mathrm{O}\right)$, and the toxic effects of high ammonia nitrogen levels on plants, a $\mathrm{C} / \mathrm{N}$ ratio about $30-35$ should be selected for RSD amendments.

In this study, soil microbial communities were distinctly changed during RSD treatments, and this change is one of the mechanisms of RSD (Huang et al., 2016; Zhao et al., 2018). During the RSD treatments, the microbial diversity ( $\alpha$ and $\beta$ )

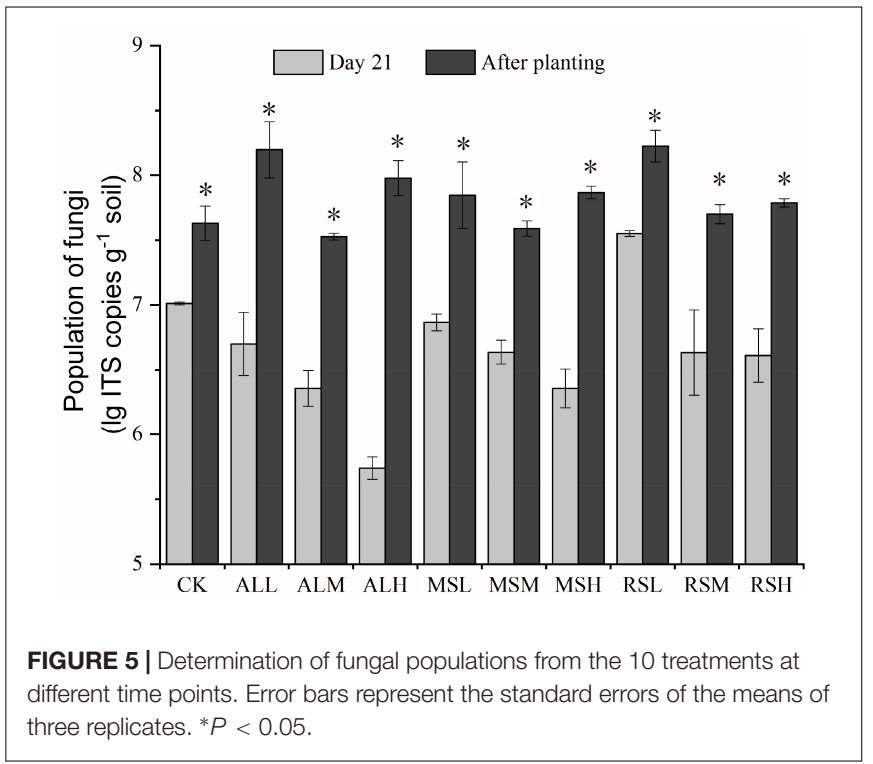

in each treated soil decreased with both bacteria and fungi (Huang et al., 2019). This is due to the fact that most aerobic bacteria and fungi are inhibited from growing in an anaerobic environment. The relative abundance of anaerobic bacteria, such as the Firmicutes, rises sharply and becomes the dominant bacteria in each treatment.

In bacteria, during the RSD treatment, the products $N$-acetyl$\beta$-glucosaminidase and $\beta$-glucosidase from Flavisolibacter (Yoon and Im, 2007) (phylum Bacteroidetes) and the $\beta-N$ acetylhexosaminidase and exo-type $\beta$-glycosidase produced by Symbiobacterium (phylum Firmicutes) (Suzuki et al., 1988; Ohno et al., 2000; Ogawa et al., 2006) possibly contributed to the degradation of organic material. In our study, the relative abundances of Flavisolibacter and Symbiobacterium in the MSL, RSM, and ALL groups were higher than those in the CK group, and a low level of substrate addition (0.5\%) resulted in significantly higher abundances than a high level of substrate 

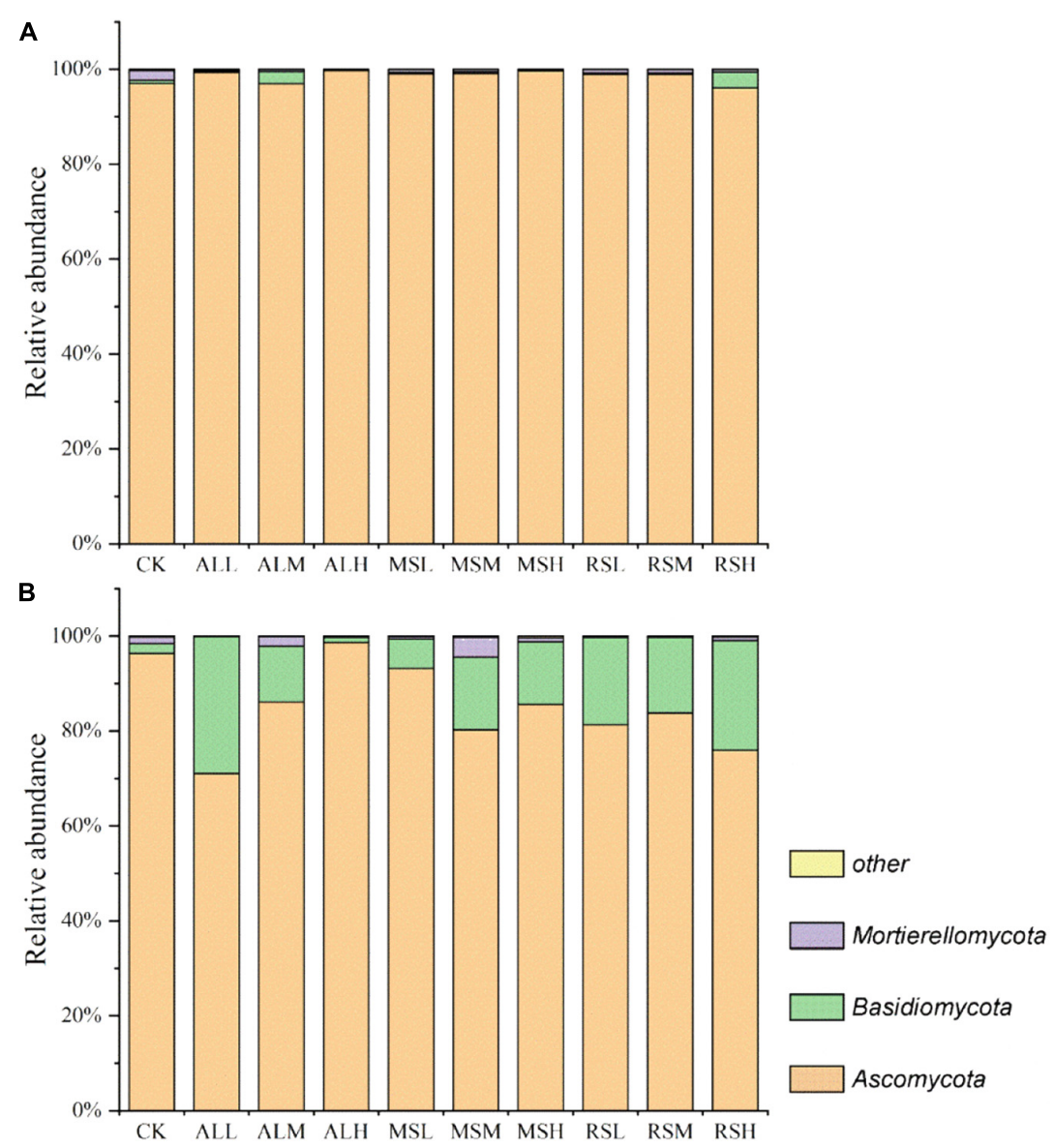

FIGURE 6 | Relative abundances (\%) of individual taxonomic groups of the fungal phyla present in samples from the 10 treatments. (A,B) Day 21 and after tomato planting, respectively. The fungal phyla with a relative abundance lower than $1 \%$ in all the treatments were clustered as "other."

addition (5\%) in the MS and AL treatment groups. Compared with days 7 and 14, on day 21, Flavisolibacter was significantly reduced in the MSL, RSL, RSM, and ALL groups. There were two possible reasons for this result. First, Flavisolibacter is an aerobic bacterium (Kim et al., 2018); greater substrate addition would result in more favorable formation of an anaerobic environment (Wen et al., 2015), and therefore, a high addition amount was not conducive to the growth of Flavisolibacter. Second, during the early stage of cultivation, residual oxygen in the soil and dissolved oxygen in the water could provide conditions for the survival of Flavisolibacter; Flavisolibacter increased rapidly in the presence of a sufficient carbon source. Therefore, lack of oxygen during the later period led to a decrease in the abundance of Flavisolibacter.

Previous reports have demonstrated that organic acids produced in RSD treatment have important inhibitory effects on pathogens (Momma et al., 2006; Huang et al., 2014). Most of the producers of these organic acids belong to Firmicutes, such as Sedimentibacter, Desulfosporosinus, Oxobacter, Clostridium, and Coprococcus. Sedimentibacter (Imachi et al., 2016), Desulfosporosinus (Stanley and Southam, 2018), Oxobacter (Bengelsdorf et al., 2015), Clostridium (Braun et al., 1981), and Coprococcus (Holdeman and Moore, 1974) are effective producers of acetic acids, butyric acid, and propionic acid. During RSD treatment, some genera of Firmicutes showed significant changes compared with the CK group, and the relative abundances of organic acid producers in the CK group were less than $1 \%$ throughout the soil treatment period. However, after RSD treatments, the relative abundances of organic acid producers increased, particularly in the AL groups, potentially because many Firmicutes are anaerobic bacteria and the low $\mathrm{C} / \mathrm{N}$ ratio is more conducive to the formation of an anaerobic environment (Liu et al., 2016). In addition, the higher addition of substrate was related to higher relative abundance of organic acid producers, similar to the results of a study by Wen (2015). Once pathogens are inhibited, toxic organic acids are degraded during the drying process of the soil due to destruction of the anaerobic environment, thereby preventing toxicity during crop cultivation. In addition to producing these organic acids to inhibit pathogens, Desulfosporosinus and Bacillus have been shown to produce sulfide and low-valence metal ions $\left(\mathrm{Fe}^{2+}, \mathrm{Mn}^{2+}\right)$ (Boone et al., 1995; Stanley and Southam, 2018), respectively, and are also involved in the disinfestation process of RSD (Runia et al., 2014). Notably, during RSD treatment, the relative abundance of Desulfosporosinus reached a maximum 


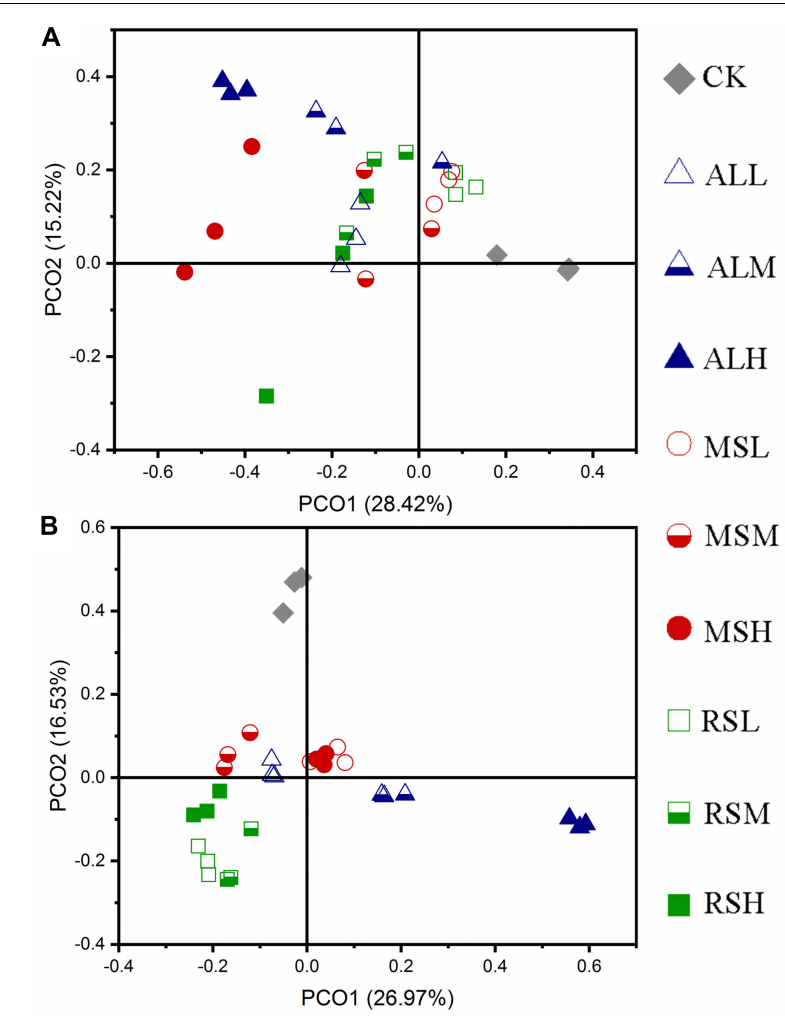

FIGURE 7 | Principal coordinate analysis for the dissimilarities of fungal microbial communities in different soils. (A,B) Day 21 and after tomato planting, respectively. PCoA of fungi based on the bray_curtis index.

of only $0.1 \%$ in the CK group, which could also explain why there was a lack of pathogen inhibition. After tomato planting, the relative abundances of genera with disease resistance, phosphorus solubilization, or nitrogen fixation ability, such as Bacillus (Ji et al., 2008; Jeong et al., 2012), Clostridium, Streptomyces (Watve et al., 2001), and Flavisolibacter (Mpanga et al., 2018), were significantly higher in the RSD treatment with $0.5 \%$ substrate addition than in the CK group, corresponding to the results of tomato plant biomass.

Reductive soil disinfestation treatments clearly reduced the levels of fungal pathogens. Penicillium and Fusarium can cause plant disease (Larkin and Fravel, 1998; Meng et al., 2017). Additionally, the abundances of Penicillium and Fusarium in some RSD treatments were higher than those in the CK group on day 7; notably, addition of more substrate increased the abundances of Penicillium and Fusarium. Moreover, over time, the abundances of Penicillium and Fusarium in the RSD treatments gradually decreased. However, the abundance of Penicillium in the CK group also decreased with time, indicating that the CK treatment could effectively inhibit Penicillium under pure flooding and anaerobic conditions. For Fusarium, pure flooding did not inhibit Fusarium; however, the RSD treatments significantly reduced the abundance of Fusarium. On day 21, the relative abundances of Fusarium in RSD treatments, except the MSM and RSL treatments, were reduced to less than $1 \%$, and those in $\mathrm{AL}$ treatment groups were reduced to below
$0.1 \%$. This confirmed the findings of Liu (2016), demonstrating that lower $\mathrm{C} / \mathrm{N}$ ratios were associated with better disinfestation efficiencies. Many previous studies have also shown that RSD can effectively suppress Fusarium (Larkin and Fravel, 1998; Huang et al., 2014; Meng et al., 2017). Notably, for the pathogen Aspergillus (Wang et al., 2017), by day 21, RSD treatments effectively suppressed Aspergillus, and the relative abundance in the CK group was clearly higher than those in all RSD treatment groups, consistent with the results of Huang et al. (2016). Furthermore, after tomato planting, the abundances of Fusarium and Aspergillus in the CK group were dramatically higher than those in the RSD treatment groups, demonstrating that RSD had persistent effects.

Interestingly, some fungi (Pseudallescheria before planting, Arthrographis after planting) were extremely abundant in the ALH group, both before and after planting. These results could be explained by the high nitrogen concentrations encountered after ALH treatment, which would be suitable for the survival and rapid propagation of these fungi. However, this will reduce the microbial diversity in the soil and is not conducive to soil health.

Reductive soil disinfestation treatments can effectively inhibit soil-borne diseases (Meng et al., 2019), but plant growth is not only dependent on healthy soil, but also inseparable from adequate nutrition. In our study, the dry weights of the leaf, stem, and root of the MSL treatment were significantly higher than in the CK treatment, while the leaf, stem and root dry weights of the $\mathrm{ALH}$ and RSH treatments were notably lower than CK treatment. In fact, in terms of pathogenic bacteria, these three treatments have significant inhibitory effects on pathogenic bacteria, but in terms of nitrogen, when the substrate is added at $5 \%$, the low $\mathrm{C} / \mathrm{N}$ in $\mathrm{ALH}$ treatment caused ammonia toxicity. High $\mathrm{C} / \mathrm{N}$ in the RSH treatment caused a serious deficiency of nitrogen. This has a certain negative impact on the growth of tomatoes. Based on the results of Penicillium, Fusarium, Pseudallescheria, and Arthrographis, in order to balance the relationships among pathogens, substrate addition, and disinfestation effects, we must consider the optimal amount of organic materials in the RSD treatments. For example, in soils in which soil-borne diseases are not serious, we can give priority to adding $0.5 \%$ substrate and achieving a $\mathrm{C} / \mathrm{N}$ ratio of about 30:1 (e.g., MS) for the substrate. Additionally, if RS is applied, sufficient nitrogen fertilizer should be added during crop cultivation. In contrast, for soils with more serious soil-borne diseases, lower $\mathrm{C} / \mathrm{N}$ ratios for the substrate can be selected, and the amount of input can be increased.

\section{CONCLUSION}

We examined the effects of different RSD treatments on microbial community structures. Notably, the biomasses of tomatoes in the MSL, MSM, and ALL groups were higher than those in the CK group. Corresponding to changes in microbial communities, after tomato planting, the relative abundances of some beneficial bacteria, such as Bacillus, Clostridium, Flavisolibacter, and Streptomyces, were significantly increased in the MSL, MSM, and ALL groups compared with those in the CK group. At the same 
time, the relative abundances of pathogenic bacteria, such as Fusarium and Aspergillus, were significantly lower than in the CK group. Although pathogen inhibition was better for treatments with higher substrate concentrations, when the $\mathrm{C} / \mathrm{N}$ ratio was too low, ammonia toxicity occurred in tomato plants, and rapid proliferation of some fungi that were detrimental to plant growth and soil health was observed, particularly for the ALH group. Therefore, in this study, based on our comprehensive analysis of disinfestation effects and tomato growth status, $0.5 \%$ substrate addition was found to be suitable for RSD treatment, compared to $2 \%$ and $5 \%$ substrate addition. However, when the $\mathrm{C} / \mathrm{N}$ ratio is higher than 33, the addition amount could be appropriately increased. If considering some fungi (e.g., Pseudallescheria and Arthrographis) that can grow rapidly in a low $\mathrm{C} / \mathrm{N}$ environment, the optimal substrate $\mathrm{C} / \mathrm{N}$ ratio may be approximately 30 .

\section{DATA AVAILABILITY STATEMENT}

The datasets generated for this study can be found in the NCBI (SRA accession: PRJNA523309).

\section{REFERENCES}

Bengelsdorf, F. R., Poehlein, A., Schiel-Bengelsdorf, B., Daniel, R., and Durre, P. (2015). Genome sequence of the acetogenic bacterium Oxobacter pfennigii DSM 3222T. Genome Announc. 3:e1408-15. doi: 10.1128/genomeA.01408-15

Blok, W. J., Lamers, J. G., Termorshuizen, A. J., and Bollen, G. J. (2000). Control of soilborne plant pathogens by incorporating fresh organic amendments followed by tarping. Phytopathology 90, 253-259. doi: 10.1094/PHYTO.2000.90. 3.253

Boone, D. R., Liu, Y. T., Zhao, Z. J., Balkwill, D. L., Drake, G. R., Stevens, T. O., et al. (1995). Bacillus-infernus sp-nov, an fe(iii)-reducing and $\mathrm{mn}$ (iv)-reducing anaerobe from the deep terrestrial subsurface. Int. J. Syst. Bacteriol. 45, 441-448. doi: 10.1099/00207713-45-3-441

Braun, M., Mayer, F., and Gottschalk, G. (1981). Clostridium aceticum (Wieringa), a microorganism producing acetic acid from molecular hydrogen and carbon dioxide. Arch. Microbiol. 128, 288-293. doi: 10.1007/bf00422532

Butler, D. M., Kokalis-Burelle, N., Albano, J. P., McCollum, T. G., Muramoto, J., and Rosskopf, E. N. (2014). Anaerobic soil disinfestation (ASD) combined with soil solarization as a methyl bromide alternative: vegetable crop performance and soil nutrient dynamics. Plant Soil 378, 365-381. doi: 10.1007/s11104-0142030-z

Butler, D. M., Kokalis-Burelle, N., Muramoto, J., Shennan, C., McCollum, T. G., and Rosskopf, E. N. (2012). Impact of anaerobic soil disinfestation combined with soil solarization on plant-parasitic nematodes and introduced inoculum of soilborne plant pathogens in raised-bed vegetable production. Crop Prot. 39, 33-40. doi: 10.1016/j.cropro.2012.03.019

Caporaso, J. G., Kuczynski, J., Stombaugh, J., Bittinger, K., Bushman, F. D., and Costello, E. K. (2010). QIIME allows analysis of high-throughput community sequencing data. Nat. Methods 7, 335-336.

Ciarlo, E., Conti, M., Bartoloni, N., and Rubio, G. (2006). The effect of moisture on nitrous oxide emissions from soil and the $\mathrm{N} 2 \mathrm{O} /(\mathrm{N} 2 \mathrm{O}+\mathrm{N} 2)$ ratio under laboratory conditions. Biol. Fertil. Soils 43, 675-681. doi: 10.1007/s00374-0060147-9

Claesson, M. J., O’Sullivan, O., Wang, Q., Nikkila, J., Marchesi, J. R., Smidt, H., et al. (2009). Comparative analysis of pyrosequencing and a phylogenetic microarray for exploring microbial community structures in the human distal intestine. PLoS One 4:e6669. doi: 10.1371/journal.pone.0006669

Di Gioia, F., Ozores-Hampton, M., Zhao, X., Thomas, J., Wilson, P., Li, Z., et al. (2017). Anaerobic soil disinfestation impact on soil nutrients dynamics and nitrous oxide emissions in fresh-market tomato. Agric. Ecosyst. Environ. 240, 194-205. doi: 10.1016/j.agee.2017.02.025

\section{AUTHOR CONTRIBUTIONS}

All authors listed have made a substantial, direct and intellectual contribution to the work, and approved it for publication.

\section{FUNDING}

This study was funded by the National Natural Science Foundation of China (41525002, 41761134085, and 31572202) and the Strategic Priority Research Program of Chinese Academy of Sciences (XDB15020301).

\section{SUPPLEMENTARY MATERIAL}

The Supplementary Material for this article can be found online at: https://www.frontiersin.org/articles/10.3389/fmicb. 2019.02851/full\#supplementary-material

Fu, H., Zhang, G., Zhang, F., Sun, Z., Geng, G., and Li, T. (2017). Effects of continuous tomato monoculture on soil microbial properties and enzyme activities in a solar greenhouse. Sustainability 9:317. doi: 10.3390/su9020317

Gadde, B., Bonnet, S., Menke, C., and Garivait, S. (2009). Air pollutant emissions from rice straw open field burning in India, Thailand and the Philippines. Environ. Poll. 157, 1554-1558. doi: 10.1016/j.envpol.2009.01.004

Guo, H., Zhao, X., Rosskopf, E. N., Di Gioia, F., Hong, J. C., and McNear, D. H. (2018). Impacts of anaerobic soil disinfestation and chemical fumigation on soil microbial communities in field tomato production system. Appl. Soil Ecol. 126, 165-173. doi: 10.1016/j.apsoil.2017.12.018

Holdeman, L. V., and Moore, W. E. C. (1974). New genus, Coprococcus, twelve new species, and emended descriptions of four previously described species of bacteria from human feces. Int. J. Syst. Bacteriol. 24, 260-277. doi: 10.1099/ 00207713-24-2-260

Huang, X., Liu, L., Wen, T., Zhang, J., Wang, F., and Cai, Z. (2016). Changes in the soil microbial community after reductive soil disinfestation and cucumber seedling cultivation. Appl. Microbiol. Biotechnol. 100, 5581-5593. doi: 10.1007/ s00253-016-7362-6

Huang, X., Wen, T., Zhang, J., Meng, L., Zhu, T., and Cai, Z. (2014). Toxic organic acids produced in biological soil disinfestation mainly caused the suppression of Fusarium oxysporum f. sp. cubense. BioControl 60, 113-124. doi: 10.1007/ s10526-014-9623-6

Huang, X., Zhao, J., Zhou, X., Zhang, J., and Cai, Z. (2019). Differential responses of soil bacterial community and functional diversity to reductive soil disinfestation and chemical soil disinfestation. Geoderma 348, 124-134. doi: 10.1016/j. geoderma.2019.04.027

Imachi, H., Sakai, S., Kubota, T., Miyazaki, M., Saito, Y., and Takai, K. (2016). Sedimentibacter acidaminivorans sp. nov., an anaerobic, amino-acid-utilizing bacterium isolated from marine subsurface sediment.Int. J. Syst. Evol. Microbiol. 66, 1293-1300. doi: 10.1099/ijsem.0.000878

Jeong, H., Jeong, D. E., Kim, S. H., Song, G. C., Park, S. Y., Ryu, C. M., et al. (2012). Draft genome sequence of the plant growth-promoting bacterium Bacillus siamensis KCTC 13613T. J. Bacteriol. 194, 4148-4149. doi: 10.1128/JB.00805- 12

Ji, X., Lu, G., Zheng, C., and Mu, Z. (2008). Biological control against bacterial wilt and colonization of mulberry by an endophytic Bacillus subtilis strain. FEMS Microbiol. Ecol. 65, 565-573. doi: 10.1111/j.1574-6941.2008.00543.x

Khalil, M. I., Hossain, M. B., and Schmidhalter, U. (2005). Carbon and nitrogen mineralization in different upland soils of the subtropics treated with organic materials. Soil Biol. Biochem. 37, 1507-1518. doi: 10.1016/j.soilbio.2005.01.014

Kim, D. U., Lee, H., Lee, S., Kim, S. G., Park, A. Y., Ahn, J. H., et al. (2018). Flavisolibacter metallilatus sp nov., isolatedfrom an automotive air conditioning 
system and emended description of the genus Flavisolibacter. Int. J. Syst. Evol. Microbiol. 68, 917-923. doi: 10.1099/ijsem.0.002609

Larkin, R. P., and Fravel, D. R. (1998). Efficacy of various fungal and bacterial biocontrol organisms for control of Fusarium wilt of tomato. Plant Dis. 82, 1022-1028. doi: 10.1094/PDIS.1998.82.9.1022

Li, H., Dai, M., Dai, S., and Dong, X. (2018). Current status and environment impact of direct straw return in China's cropland - A review. Ecotoxicol. Environ. Saf. 159, 293-300. doi: 10.1016/j.ecoenv.2018.05.014

Liu, L., Kong, J., Cui, H., Zhang, J., Wang, F., Cai, Z., et al. (2016). Relationships of decomposability and $\mathrm{C} / \mathrm{N}$ ratio in different types of organic matter with suppression of Fusarium oxysporum and microbial communities during reductive soil disinfestation. Biol. Control 101, 103-113. doi: 10.1016/j. biocontrol.2016.06.011

Liu, L. L., Chen, S. H., Zhao, J., Zhou, X., Wang, B. Y., Li, Y. L., et al. (2018). Watermelon planting is capable to restructure the soil microbiome that regulated by reductive soil disinfestation. Appl. Soil Ecol. 129, 52-60. doi: 10.1016/j.apsoil.2018.05.004

Long, X. E., Wang, J., Huang, Y., and Yao, H. (2016). Microbial community structures and metabolic profiles response differently to physiochemical properties between three landfill cover soils. Environ. Sci. Poll. Res. Int. 23, 15483-15494. doi: 10.1007/s11356-016-6681-6

Long, X. E., Yao, H., Huang, Y., Wei, W., and Zhu, Y. G. (2018). Phosphate levels influence the utilisation of rice rhizodeposition carbon and the phosphatesolubilising microbial community in a paddy soil. Soil Biol. Biochem. 118, 103-114. doi: 10.1016/j.soilbio.2017.12.014

Martínez-García, L. B., Korthals, G., Brussaard, L., Jørgensen, H. B., and De Deyn, G. B. (2018). Organic management and cover crop species steer soil microbial community structure and functionality along with soil organic matter properties. Agric. Ecosyst. Environ. 263, 7-17. doi: 10.1016/j.agee.2018.04.018

Mary, B., Recous, S., Darwis, D., and Robin, D. (1996). Interactions between decomposition of plant residues and nitrogen cycling in soil. Plant Soil 181, 71-82. doi: 10.1007/bf00011294

Mazzola, M., Muramoto, J., and Shennan, C. (2018). Anaerobic disinfestation induced changes to the soil microbiome, disease incidence and strawberry fruit yields in California field trials. Appl. Soil Ecol. 127, 74-86. doi: 10.1016/j.apsoil. 2018.03.009

Meng, T., Ren, G., Wang, G., and Ma, Y. (2019). Impacts on soil microbial characteristics and their restorability with different soil disinfestation approaches in intensively cropped greenhouse soils. Appl. Microbiol. Biotechnol. 103, 6369-6383. doi: 10.1007/s00253-019-09964-z

Meng, T., Yang, Y., Cai, Z., and Ma, Y. (2017). The control of Fusarium oxysporum in soil treated with organic material under anaerobic condition is affected by liming and sulfate content. Biol. Fertil. Soils 54, 295-307. doi: 10.1007/s00374017-1260-7

Messiha, N. A. S., van Diepeningen, A. D., Wenneker, M., van Beuningen, A. R., Janse, J. D., Coenen, T. G. C., et al. (2007). Biological soil disinfestation (BSD), a new control method for potato brown rot, caused by Ralstonia solanacearum race 3 biovar 2.Eur. J. Plant Pathol. 117, 403-415. doi: 10.1007/s10658-0079109-9

Momma, N., Kobara, Y., Uematsu, S., Kita, N., and Shinmura, A. (2013). Development of biological soil disinfestations in Japan. Appl. Microbiol. Biotechnol. 97, 3801-3809. doi: 10.1007/s00253-013-4826-9

Momma, N., Yamamoto, K., Simandi, P., and Shishido, M. (2006). Role of organic acids in the mechanisms of biological soil disinfestation (BSD).J. Gen. Plant Pathol. 72, 247-252. doi: 10.1007/s10327-006-0274-z

Mowlick, S., Hirota, K., Takehara, T., Kaku, N., Ueki, K., and Ueki, A. (2012). Development of anaerobic bacterial community consisted of diverse clostridial species during biological soil disinfestation amended with plant biomass.J. Soil Sci. Plant Nutr. 58, 273-287. doi: 10.1080/00380768.2012.682045

Mpanga, I., Dapaah, H., Geistlinger, J., Ludewig, U., and Neumann, G. (2018). Soil type-dependent interactions of $\mathrm{P}$-solubilizing microorganisms with organic and inorganic fertilizers mediate plant growth promotion in tomato. Agronomy 8:213. doi: 10.3390 /agronomy 8100213

Ogawa, M., Kitagawa, M., Tanaka, H., Ueda, K., Watsuji, T. O., Beppu, T., et al. (2006). A $\beta-N$-acetylhexosaminidase from Symbiobacterium thermophilum; gene cloning, overexpression, purification and characterization. Enzyme Microb. Technol. 38, 457-464.

Ohno, M., Shiratori, H., Park, M. J., Saitoh, Y., Kumon, Y., Yamashita, N., et al. (2000). Symbiobacterium thermophilum gen. nov., sp nov., a symbiotic thermophile that depends on co-culture with a Bacillus strain for growth Int. J. Syst. Evol. Microbiol. 50, 1829-1832. doi: 10.1099/00207713-50-51829

Rosskopf, E. N., Burelle, N., Hong, J., Butler, D. M., Noling, J. W., He, Z., et al. (2014). "Comparison of anaerobic soil disinfestation and drip-applied organic acids for raised-bed specialty crop production in Florida," in Proceedings of the International Symposium on Chemical and Non-Chemical Soil and Substrate Disinfestation, Brooklyn.

Rosskopf, E. N., Serrano-Pérez, P., Hong, J., Shrestha, U., Rodríguez-Molina, M. D. C., Martin, K., et al. (2015). Anaerobic soil disinfestation and soilborne pest management. Organ. Am. Soil Suppressive. Plant Dis. Manag. 277-305. doi: 10.1007/978-3-319-23075-7_13

Runia, W. T., Thoden, T. C., Molendijk, L. P. G., van den Berg, W., Termorshuizen, A. J., Streminska, M. A., et al. (2014). "Unravelling the mechanism of pathogen inactivation during anaerobic soil disinfestation," in Proceedings of the International Symposium on Chemical and Non-Chemical Soil and Substrate Disinfestation, Brooklyn.

Serrano-Pérez, P., Rosskopf, E., De Santiago, A., and Rodríguez-Molina, M. D. C (2017). Anaerobic soil disinfestation reduces survival and infectivity of Phytophthora nicotianae chlamydospores in pepper. Sci. Hortic. 215, 38-48. doi: 10.1016/j.scienta.2016.12.003

Shennan, C., Muramoto, J., Lamers, J., Mazzola, M., Rosskopf, E. N., KokalisBurelle, N., et al. (2014). Anaerobic soil disinfestation for soil borne disease control in strawberry and vegetable systems: current knowledge and future directions. Acta Hortic. 1044, 165-175. doi: 10.17660/actahortic.2014.1044.20

Shrestha, U., Rosskopf, E. N., Butler, D. M., and Fried, G. (2018). Effect of anaerobic soil disinfestation amendment type and C:N ratio on Cyperus esculentus tuber sprouting, growth and reproduction. Weed Res. 58, 379-388. doi: 10.1111/wre. 12318

Stanley, W., and Southam, G. (2018). The effect of gram-positive (Desulfosporosinus orientis) and gram-negative (Desulfovibrio desulfuricans) sulfate-reducing bacteria on iron sulfide mineral precipitation. Can. J. Microbiol. 64, 629-637. doi: 10.1139/cjm-2017-0545

Suzuki, S., Horinouchi, S., and Beppu, T. (1988). Growth of a tryptophanaseproducing thermophile, symbiobacterium-thermophilum gen-nov, sp-nov, is dependent on co-culture with a Bacillus sp. J. Gen. Microbiol. 134, 2353-2362. doi: 10.1099/00221287-134-8-2353

Wang, T., Li, P., Zhang, Q., Zhang, W., Zhang, Z., Wang, T., et al. (2017). Determination of Aspergillus pathogens in agricultural products by a specific nanobody-polyclonal antibody sandwich ELISA. Sci. Rep. 7:4348. doi: 10.1038/ s41598-017-04195-6

Watve, M. G., Tickoo, R., Jog, M. M., and Bhole, B. D. (2001). How many antibiotics are produced by the genus Streptomyces? Arch. Microbiol. 176, 386-390. doi: $10.1007 / \mathrm{s} 002030100345$

Wen, T., Huang, X., Zhang, J., and Cai, Z. (2015). Effects of biological soil disinfestation and water regime on suppressing Artemisia selengensis root rot pathogens.J. Soils Sediments 16, 215-225. doi: 10.1007/s11368-015-1172-9

Xu, M., Chen, X., Qiu, M., Zeng, X., Xu, J., Deng, D., et al. (2012). Barcoded pyrosequencing reveals the responses of PBDE-degrading microbial communities to electron donor amendments. PLoS One 7:e30439. doi: 10.1371/ journal.pone. 0030439

Yoon, M. H., and Im, W. T. (2007). Flavisolibacter ginsengiterrae gen. nov., sp. nov. and Flavisolibacter ginsengisoli sp. nov., isolated from ginseng cultivating soil. Int. J. Syst. Evol. Microbiol. 57(Pt 8), 1834-1839. doi: 10.1099/ijs.0.65011-0

Zhao, J., Zhou, X., Jiang, A., Fan, J., Lan, T., Zhang, J., et al. (2018). Distinct impacts of reductive soil disinfestation and chemical soil disinfestation on soil fungal communities and memberships. Appl. Microbiol. Biotechnol. 102, 7623-7634. doi: 10.1007/s00253-018-9107-1

Conflict of Interest: The authors declare that the research was conducted in the absence of any commercial or financial relationships that could be construed as a potential conflict of interest.

Copyright $\odot 2019$ Tan, Liao, Shu and Yao. This is an open-access article distributed under the terms of the Creative Commons Attribution License (CC BY). The use, distribution or reproduction in other forums is permitted, provided the original author(s) and the copyright owner(s) are credited and that the original publication in this journal is cited, in accordance with accepted academic practice. No use, distribution or reproduction is permitted which does not comply with these terms. 